Determinants of crop-livestock integration in Brazil: Evidence from the household and regional levels

\author{
J. D. B. Gil ${ }^{\mathrm{a}^{*}}$, R. Garrett $\mathrm{a}^{\mathrm{a}}$, T. Berger ${ }^{\mathrm{b}}$ \\ aDDepartment of Earth and Environment, Boston University, Boston, MA 02215, USA. \\ ${ }^{b}$ Institute of Land Use Economics in the Tropics and Subtropics, University of Hohenheim, Stuttgart, \\ 70599, Germany.
}

*Corresponding author: J. D. B. Gil-judbgil@gmail.com

(C) 2016. This manuscript version is made available under the Elsevier user license http://www.elsevier.com/open-access/userlicense/1.0/ 


\title{
Determinants of crop-livestock integration in Brazil: Evidence from the household and regional levels
}

\begin{abstract}
Integrated crop-livestock systems (iCL) are advocated as a promising strategy to increase agricultural production and rehabilitate degraded pastures while mitigating GHG emissions. Although $\mathrm{iCL}$ in Brazil has increased over the past few years, it still occupies a small share of the country's total agricultural area. We investigate the determinants of $\mathrm{iCL}$ occurrence in Mato Grosso state, a globally important producer of beef cattle and grains that has experienced rapid land cover change and environmental degradation in recent decades. Our analysis encompasses two typical cases of $\mathrm{iCL}$ in Mato Grosso (the rotation of soy followed by pasture, and soy followed by maize and pasture) as well as biophysical, socioeconomic, and institutional factors observable at the household and/or municipality levels that may influence the wide-scale occurrence of $\mathrm{iCL}$. Evidence at both scales suggests that knowledge and supply chain infrastructure play an important role in early occurrence of $\mathrm{iCL}$, as they are more common in regions closer to $\mathrm{iCL}$ research stations and processing facilities of grains and cattle. On average $\mathrm{iCL}$ adopters are more educated and have better access to technical assistance and sector information than specialized farmers or ranchers. Most iCLs are concentrated near established soy areas and greater similarity exists between municipalities with $\mathrm{iCL}$ and soy-dominant municipalities vs. pasture-dominant municipalities. Our findings reveal the importance of specific conditions for $\mathrm{iCL}$ occurrence and $\mathrm{iCL}$ promotion in livestock-dominant regions. Incentives targeted at ranchers are crucial for the achievement of the Brazilian Government's goal to restore degraded pastures through agricultural intensification.
\end{abstract}

\section{Key-words}

Integrated systems; sustainable intensification; agricultural technology diffusion; land cover change; pasture degradation. 


\section{Introduction}

Deforestation for export-oriented agricultural expansion has become a leading driver of environmental change in tropical regions (Lambin \& Meyfroidt 2011; DeFries et al. 2013). This trend has been particularly concerning in the Brazilian Amazon and Cerrado biomes, which contain globally significant repositories of carbon and biodiversity and play a critical role in regional hydrological cycles (Klink \& Machado 2005; Peres et al. 2010; Davidson et al. 2012; Spera et al. 2016). Since 2004, when deforestation reached its peak, agricultural production in Brazil has appeared increasingly decoupled from forest clearance as a result of improved public and private anti-deforestation policies (Nepstad et al. 2014; Soares-Filho et al. 2010; Assunção et al. 2012; Macedo et al. 2012; Gibbs et al. 2015). However, low levels of deforestation for agriculture persist in many Amazonian regions (Godar et al. 2014; INPE 2015) and the rapid clearing of the Cerrado for the expansion of commodity agriculture remains a pressing conservation challenge (Spera et al. 2016).

In an effort to prevent further deforestation and associated greenhouse gases (GHG) emissions, the Brazilian Federal Government has been investing in technologies able to increase crop and livestock productivity while restoring degraded lands (Government of Brazil 2014). Particular attention has been directed at the cattle sector, where the largest opportunities to improve productivity exist, since roughly $20 \%$ of Brazil's total land area is devoted to pastures that support on average less than one animal per hectare (IBGE 2006; Cohn et al. 2014; Strassburg et al. 2014). Although improved productivity cannot always guarantee land sparing (Angelson \& Kaimowitz 2008), it is considered a necessary complement to more direct conservation policies for the maintenance of agricultural production growth (Godfray et al. 2010; Tilman et al. 2011).

One promising strategy to improve livestock productivity in Brazil is the use of integrated crop-livestock systems (iCL), here defined as the periodic rotation of crops, pasture, and livestock on the same land area. The combination of farming and grazing within the same area leads to synergies between system components that can generate higher outputs, cost savings and enhanced ecosystem services. In particular, $\mathrm{iCL}$ have been shown to improve crop and pasture yields and subsequent animal growth through enhanced soil fertility (Salton et al. 2014; 
Carvalho et al. 2014; Lemaire et al. 2014). iCL can also reduce net GHG emissions and nutrient runoff per unit of agricultural production by better recycling animal manure and crop residues and decreasing the time needed for cattle to reach slaughter weight (Alvim et al. 2015). As a consequence, $\mathrm{iCL}$ may offer increased resilience against economic and biophysical stresses versus specialized (e.g. continuous) cropping or pasture operations (FAO 2007; Thornton \& Herrero 2015). Nevertheless, some forms of $\mathrm{iCL}$ such as integrated beef-maize production may involve high levels of synthetic inputs and low species and habitat diversity as compared to other mixed systems (Bungenstab 2012).

Due to their theoretical economic and ecological advantages, $\mathrm{iCL}$ have been proposed as a strategy to stem agricultural expansion, pasture degradation and deforestation reduction. This is particularly true in the Brazilian state of Mato Grosso, which spans the Amazon and Cerrado biomes and has the largest soybean area ( 8.6 million hectares), pasture area (26 million hectares) and cattle herd (28 million animals) in the country (CONAB 2014; IMEA 2010). At least 2 million hectares of this pasture area are categorized as degraded (IMEA 2010) and most support cattle stocking rates as low as 0.5 animal per hectare in some regions, resulting in high GHG emissions (IMEA 2010; Galford et al. 2010). It has been proposed that the use of iCL in place of extensive, specialized pasture management could more than double the stocking rates of degraded pastures and improve soil quality where organic matter has been lost after years of monoculture (Observatorio ABC 2014a,b; Peron \& Evangelista 2004; Oliveira et al. 2003).

In order to boost adoption of $\mathrm{iCL}$ and promote cattle intensification, Brazilian authorities approved the National Policy of Integrated Crop-Livestock-Forestry Systems (Government of Brazil 2013) and created a new EMBRAPA ${ }^{1}$ unit exclusively dedicated to the research and development of integrated systems. In addition, the Ministry of Agriculture launched the LowCarbon Agricultural Plan (or simply "ABC Plan") in 2010 to facilitate capacity building, improve technical assistance and provide special credit lines to farmers adopting low-carbon agricultural practices - including $\mathrm{iCL}$, no-till farming, biological nitrogen fixation, restoration of degraded pastures, commercial forest plantations and treatment of animal residues (Government of Brazil 2011). The Plan is part of the country's National Policy for Climate Change, which defines a voluntary target for GHG emissions reduction of $36.1 \%-38.9 \%$ by 2020 relative to emissions projections for that year (Government of Brazil, 2009). Among other goals, the ABC Plan aims to

\footnotetext{
${ }^{1}$ EMBRAPA (in Portuguese, "Empresa Brasileira de Pesquisa Agropecuária") is the Brazilian National Agricultural Research Institute.
} 
increase the use of integrated systems by 4 million hectares, which is expected to avoid the emission of 18-22 million tons of carbon dioxide equivalent (CNA 2012).

According to official estimates based on $\mathrm{PROBIO}^{2}$ data, the potential area for integrated system expansion in the entire country is greater than 67 million hectares, but until 2010 these systems occupied only 1.5 million hectares (Balbino et al. 2011). The adoption of integrated systems across Mato Grosso has been particularly slow, reaching only 90,000 ha (or $0.4 \%$ of the state's agricultural area in 2010) (Balbino et al. 2011). Additionally, less than $5 \%$ of all ABC loans issued by 2014 had been allocated to integrated systems (Observatorio ABC 2013).

Understanding the drivers and constraints of $\mathrm{iCL}$ occurrence within Brazil is essential for the successful implementation of climate-related policies put forward by the Brazilian Government. It may also offer insights into their potential viability as a climate smart, sustainable intensification strategy in regions where extensive cattle ranching persists. Yet, to the best of our knowledge, no study has ever tried to capture the aggregate effect of biophysical, socioeconomic and institutional requirements for $\mathrm{iCL}$ occurrence or its spatial variation in the region. Existing case studies of individual farms and localized experiments offer important insights into the economic and environmental benefits of agricultural integration under specific conditions, but do not elucidate the barriers to scaling up integrated production.

In this paper we examine the main factors associated with the occurrence of iCL in Mato Grosso. We argue that $\mathrm{iCL}$ systems have unique characteristics that distinguish them from specialized agricultural systems, and propose an analytical framework based on specific adoption determinants that arise from these characteristics. We test the extent to which variables observable at the household and municipality scales are associated with $\mathrm{iCL}$ occurrence and then compare the findings from both scales. We conclude by discussing these findings in light of past research on agricultural land use decisions, and identify potential leverage points for promoting $\mathrm{iCL}$ from a public policy perspective.

\footnotetext{
${ }^{2}$ PROBIO (in Portuguese, "Projeto de Conservação e Utilização Sustentável da Diversidade Biológica Brasileira") is a project for the conservation and sustainable use of the Brazilian biological diversity for which land cover maps of all Brazilian biomes were generated. PROBIO is conducted by the Brazilian Ministry of Environment and co-funded by the Brazilian Federal Government, the Global Environmental Facility (GEF), and the World Bank.
} 


\section{Background and analytical framework}

The literature on the numerous factors influencing land use decisions is abundant. Such factors include prices of agricultural products and inputs (Richards et al. 2012; Garrett et al. 2013a); agricultural, environmental, and fiscal policies (Schnepf et al. 2001, Garrett et al. 2013b); soils, topography, and climate (Vera-Diaz et al. 2008; Mann et al. 2014; Spera et al. 2014); transportation costs (Walker et al., 2009); and household socioeconomic conditions, such as land tenure, indebtedness, age, education, experience and farm size (Lee 2005; Knowler \& Bradshaw 2007). However, few studies have attempted to assess the determinants of more specific land management practices (e.g. crop-livestock rotations, fertilizer usage, no-till planting, or irrigation) in Brazil.

The decision of whether to manage the land via $\mathrm{iCL}$ versus specialized systems (specifically continuous cropland or pasture) involves many utility tradeoffs. These may include, among others, trading increased resilience to climate and market shocks and higher payouts in the long run for simplicity, lower labor needs, as well as certain payouts in the short run (Garrett et al. 2015). Because $\mathrm{iCL}$ involve more than one type of agricultural production, they may require greater labor intensity and higher investment costs than specialized systems. As such, labor availability, tenure security and farmers' preferences concerning risk and leisure are all factors that may influence the adoption of iCL (Sulc \& Tracy 2007; Garrett et al. 2015; Bonaudo et al. 2014; Lemaire et al. 2014; Alves et al., 2015; Thornton \& Herrero 2015). The level of local supply chain infrastructure (e.g. transportation networks, storage facilities and input retailers) is a crucial limitation of agricultural development in Brazil (Bowman et al. 2012; Garrett et al. 2013a; VanWey et al. 2013) and may co-determine the economic feasibility of crop-livestock integration. Access to information and technical assistance via formal channels (e.g. state research agencies), social networks (e.g. neighbors and cooperatives) or local agribusinesses is also relevant for $\mathrm{iCL}$ adoption where it is still a novel technology. The costs of transitioning from a segregated to an integrated production system may be high (Balbino et al. 2011), which makes the availability of financial capital a potentially important $\mathrm{iCL}$ adoption requirement. Finally, in some regions, cultural norms concerning the prestige of cattle ownership and ranching as a lifestyle may influence farming decisions (Hoelle 2011). In Mato Grosso, specialized farmers and ranchers have shown different perceptions and attitudes towards integrated systems, reflecting 
how the two groups differ in terms of demographic characteristics, risk aversion and attachment to the land (Gil et al., 2015).

The set of factors that influence $\mathrm{iCL}$ adoption can thus be summarized as: capital availability, costs of adoption versus non-adoption, supply chain infrastructure, biophysical suitability, availability of skilled labor, access to information and know-how, as well as the willingness to diversify production (Figure 1). Capital availability determines a household's ability to undertake high upfront costs and is a function of income, savings (or debt) and access to credit. From an aggregate perspective, capital availability depends on the aggregate economic activity in each municipality and overall credit allocations to that region from the government. Related to capital availability are the costs associated with iCL adoption versus non-adoption; the first refers to conversion costs, which are a function of farm size and current management practices, while the second refers to opportunity costs faced by each household. The existence of supply chain infrastructure is represented by the presence of input retailers, processing facilities and marketing and transportation services for all products of the iCL system - and is considered a function of past land use trajectories. Biophysical suitability refers to favorable agro-climatic conditions for farming and/or ranching, which at the property level include the soil type and slope and at the regional level include average precipitation and temperature conditions. Availability of skilled labor depends on household demographics, but also municipality-level labor markets. Access to information and know-how are a function of a farmer's education level but also whether he or she obtains technical support through social networks, private consultants or trainings and whether demonstration units of new technologies are present at the municipality level. The only variable uniquely relevant at the household level is willingness to diversify production, which is related to individual preferences regarding complexity, leisure, risk and time - and which may be correlated with cultural and geographic backgrounds (Daugstad et al. 2006; Nielsen \& Reenberg 2010).

\section{FIGURE 1 - SEE ATTACHMENT}




\section{Material and methods}

We examine the determinants of $\mathrm{iCL}$ occurrence at both the household and municipality scales. Data, variables and models used for each of these scales are outlined below.

\subsection{Data}

In order to analyze $\mathrm{iCL}$ occurrence at the household and municipality levels in Mato Grosso we used primary data collected by the first author in 2012/13 during field work. Farms with integrated systems were identified over a period of six months through key informants and local institutions - particularly producers' unions, associations, agribusinesses and private consultants. The original database was updated with information obtained through Mato Grosso's Institute of Agricultural Economics (IMEA) and Observatorio ABC, a Brazilian think tank that monitors the $A B C$ Plan.

At the household level, non-adopters of integrated systems were sampled in the same or adjacent municipality whenever possible, as described in Gil et al. (2015). In total, the survey included 145 respondents of which 54 were $\mathrm{iCL}$ adopters, 59 were specialized soy farmers and 32 were specialized cattle ranchers. ${ }^{3}$ Survey respondents were asked about their personal preferences, resource endowments, tenure rights, farm characteristics, membership to cooperatives and professional associations, as well as access to credit, information and technical assistance.

Data used in our municipality level analysis were gathered from a variety of publicly accessible databases and websites (Table 2), except for data on cropland and pasture area which were acquired from Cohn et al. (2016). The municipality-level analysis was conducted in all of the 141 municipalities of Mato Grosso state.

Although the $\mathrm{iCL}$ systems found in Mato Grosso may show slightly different characteristics in terms of the species used, rotation frequency, and management practices, the typical iCL

\footnotetext{
${ }^{3}$ While the original study by Gil et al. (2015) sampled farms with any type of integrated system, we utilize only the data from farms with iCL systems, which comprised $89 \%$ of the original sample. Those with forestry were excluded from this analysis because their adoption requirements are quite different.
} 
consists of the rotation of soy followed by pasture for beef cattle, or soy followed by maize followed by pasture. On average, the rotation between cropland and pasture is done every two years with about a third of the total farm area in cropland at any given point. Soy and maize are usually grown within the same year. In a different type of $\mathrm{iCL}$, grass may be intercropped with maize after soy is harvested, in which case rotation happens on an annual basis. As integration is often combined with minimum-tillage, grass species of high biomass production tend to be preferred.

Due to the recent nature of the $\mathrm{iCL}$ diffusion process, we consider all $\mathrm{iCL}$ systems irrespective of how long each of them has been in place. In 2012/13, mapped farms had on average three years of experience with $\mathrm{iCL}$ and more than $90 \%$ of the respondents expressed their intention to maintain or increase the amount of land they allocated to rotation between cropland and pasture in the future. Likewise, no sampling restrictions were put on the area of integration since the incorporation of even a small amount of cropland or pasture into a formerly specialized farm would involve investment costs and substantial changes in managerial intensity and risk.

\subsection{Variables}

The specific variables used to represent each of the terms of the above equation are listed in Table 1 and Table 2 along with their descriptive statistics and, in the case of secondary data, respective sources. The inclusion of these variables in the model follows the rationale outlined in Figure 1, but some variables warrant additional explanation. "Topography" and "sandy soils", which are included in the household analysis as proxies for biophysical suitability, were repeatedly cited by farmers as influential to their decision to adopt iCL. Excessively steep slopes inhibit crop production by restricting the use of mechanized equipment, while excessively sandy soils may inhibit crop production - especially in regions with low rainfall, through impacts on soil moisture ${ }^{4}$. Both variables - described in Table 1 - reflect farmers' own perception of their properties, as they rarely operate based on spatially-explicit soil maps. "Region of origin" refers to the region where the farmer was born and controls for unobserved cultural factors at the household level that are likely to influence his or her willingness to diversity production.

\footnotetext{
${ }^{4}$ While excessive clay content is a barrier to mechanized crop production in many parts of the Amazon due to soil compaction and low permeability, excessive sand content is a more common problem in Mato Grosso (Bolliger et al. 2006).
} 
According to previous studies, farmers from Southern Brazil who migrated to Mato Grosso in the 1970 s and 80 s often opt for maintaining their tradition of specialized grain production (Jepson, 2006). "Maize area" is a proxy for the double cropping of soy with maize, one of the most profitable land uses in Mato Grosso over recent years (VanWey et al. 2013). If iCL is perceived as a competing rather than complementary intensification strategy, then the presence of double cropping could serve as a barrier to $\mathrm{iCL}$. On the other hand, double cropping could increase the chances of $\mathrm{iCL}$ occurrence given that maize is commonly used as cattle feed and the farmers who engage in these systems are already managing more diversified agricultural production.

We control for the presence of federally inspected slaughterhouses and soybean processing facilities, as well as lagged soy area and cattle herd size in each municipality. They are used as proxies for whether sufficient supply chain infrastructure exists to undertake both soy and cattle production - possibly a condition for the occurrence of $\mathrm{iCL}$ systems. We also examine the presence of Amaggi Group farms as an additional indicator of supply chain infrastructure and opportunity costs. Founded by Blairo Maggi, one of the world's largest individual soybean producers whose biography is closely related to the expansion of the soy industry and past deforestation in Mato Grosso, the Amaggi Group is a unique trader in the region (Stickler \& Almeida, 2008). Besides possessing vertically integrated supply chains (from farm to port), its production decisions are oriented by strong trade linkages with Europe, growing brand identity as an environmentally responsible (and often non-GM) soy producer, as well as enhanced capacity for traceability (Garrett et al. 2013c). Being located within close proximity to this niche trader could reduce the incentives of specialized soy farmers to adopt $\mathrm{iCL}$ by increasing the opportunity costs of diverting land and other inputs from soy production to pasture production. Conversely, improved access to high value soy markets could increase the incentives of specialized cattle ranchers to adopt iCL.

\subsection{Statistical model}

The first part of our study was aimed at examining the determinants of iCL occurrence. To do so, we used the following model:

$$
Y_{i}=\alpha+\beta_{1} K_{i}+\beta_{2} C_{i}+\beta_{3} S_{i}+\beta_{4} B_{i}+\beta_{5} L+\beta_{6} I_{i}+\beta_{7} D_{i}+\varepsilon_{i}
$$


where $Y_{i}$ indicates $\mathrm{iCL}$ occurrence, $K$ represents capital availability, $C$ represents direct and opportunity costs, $S$ represents supply chain infrastructure, $B$ represents biophysical suitability, $L$ represents labor availability, I represents information access, $D$ represents willingness to diversify production, $\alpha$ is the intercept, $\beta_{1-7}$ are the regression coefficients, and $\varepsilon$ is the residual. When the model is used in the municipality-level analysis, the index " $i$ " represents each municipality; when the model is applied at the household-level analysis, "i" represents each household. The variables included at each scale as proxies for the seven major determinants outlined above are detailed in Tables 1 and 2.

For the household analysis we applied a logistic regression with a binary dependent variable (" $Y$ " took the value of 1 if the household had adopted $\mathrm{iCL}$ and 0 otherwise). For the municipality analysis we applied an OLS regression with a continuous dependent variable (" $Y$ " represented the total number of properties with $\mathrm{iCL}$ in each municipality).

In order to check for the presence of spatial autocorrelation in our residuals, we used a rowstandardized inverse distance weights matrix based on the geographic coordinates of each municipalities' centroids (Table S5). We did not identify spatial autocorrelation in the municipality-level regression through the Moran's I test (see Table S4 in the Supplementary Information). Spatial autocorrelation could not be tested for at the household level due to lack of data on each farmers' precise location. However, it is likely that such a test would not yield further insights given that the municipalities where $\mathrm{iCL}$ adopters are situated are a subset of the municipalities with iCL systems (analyzed at the municipality level).

\section{TABLE 1 - SEE END OF DOCUMENT}

\section{TABLE 2 - SEE END OF DOCUMENT}

The second part of the study was aimed at contrasting crop, livestock and iCL occurrence at the both levels of analysis with regards to the variables identified as significant in each of the regressions above. To do so, we grouped households according to their farming activities, and municipalities according to their predominant land use (as detailed below). We then performed one-way analyses of variance with the household groups and a multivariate analysis of variance followed by Tukey's post-hoc tests with the municipality groups. Such tests allowed us to check whether the means of different groups with respect to one or more variables are significantly 
different. By checking for statistically significant differences, we could better understand the profile of different household groups and municipality groups, as well as make inferences about the likelihood of future iCL diffusion across them.

Households were sorted according to their primary activity (i.e. soy farming or cattle ranching) and whether they had adopted $\mathrm{iCL}$. In our sample, the number of rural producers with both soy and cattle but no integration was too small $(\mathrm{N}=5)$ for generating statistically robust results. Thus, we excluded these farmers from our analysis and only compared iCL adopters with specialized soy and specialized cattle producers. The low occurrence of non-integrated but mixed soy and cattle farms in our sample does not affect our results, as it is representative of broader land use patterns in the region and reflects previous findings that farmers tend to switch directly from specialized cattle or soy production to iCL (practically bypassing any mixed but non-integrated stage) (Gil et al. 2015).

Analogously, municipalities were categorized according to their predominance of soy farming or pasture and whether they had $\mathrm{iCL}$. An additional category included municipalities where both soy farming and pasture were predominant land uses but no iCL farms were identified. Soy and pasture predominance at the municipality level was calculated through a percentile-based method (see Supplementary Information). In order to prevent municipalities with very small soy or pasture areas from biasing our results, we only considered those above a pre-defined cut-off point, i.e. the $30^{\text {th }}$ percentile in terms of share of arable land dedicated to soy and pasture within each municipality. This corresponds to less than $1 \%$ of their arable land allocated to soy and approximately $21 \%$ of their arable land allocated to pasture (Table S7). The resulting categories were then arranged into four mutually exclusive categories: "iCL" (municipalities with $\mathrm{iCL}$ ); "Pa" (municipalities with pasture only); "So" (municipalities with soy only); and "SoPa" (municipalities with soy and pasture but no integration). Altogether, these four categories totaled 132 of the 141 municipalities of Mato Grosso (Table 1). Soy appeared as a major land use in all municipalities with $\mathrm{iCL}$, except for 5 municipalities which had $\mathrm{iCL}$ and pasture only. 


\section{Results}

\subsection{Household level}

The results of the household logistic regression model are expressed in Table 4 as odds ratio coefficients and marginal effects. The first represents the effect of each predictor on the probability of $\mathrm{iCL}$ occurrence, while the second expresses the absolute response of $\mathrm{iCL}$ occurrence to a change in each predictor. Producers with higher capital availability and access to information were found to be more likely to adopt $\mathrm{iCL}$ since the odds ratio coefficients are greater than 1 and marginal effects are positive. The opposite is true for producers from the South and/or producers with higher level of indebtedness (odds ratio coefficients are smaller than 1 and marginal effects are negative). Variables related to biophysical conditions and access to skilled labor were not significant. Average education level and access to technical assistance were significantly higher among $\mathrm{iCL}$ adopters than among cattle ranchers and soy farmers (Table 5 , Figure 2). Since goodness-of-fit was high (pseudo $R^{2}=0.754$, adj. $R^{2}=0.576$ ), we also performed model overfitting tests (Table S6) as described in Bilger \& Manning (2015).

\section{TABLE 4 - SEE END OF DOCUMENT}

\section{TABLE 5 - SEE END OF DOCUMENT}

\section{FIGURE 2 - SEE ATTACHMENT}

Following the logistic regression, we also checked for potential model specification errors able to indicate whether (i) all the relevant variables were included; (ii) any variables that should not be in the model were included; and (iii) the logit function was specified as a linear combination of the predictors. To do so, the original model was rebuilt using two predictors: the linear predicted value ("_hat") and the linear predicted value squared ("_hatsq"). The idea behind this test is that, in properly specified models, we should not be able to find any additional predictors that are statistically significant except by chance. Thus, “_hat” should be a statistically significant predictor since it is the predicted value from the model, while "_hatsq" should not exhibit predictive power. Our results suggested no model specification error (Table S3 in the SI). 


\subsection{Municipality level}

Access to information, attributes of the supply chain, historical land use and the level of economic development (an indicator of capital availability) were all found to be significant determinants of $\mathrm{iCL}$ occurrence (Table 6). Existing $\mathrm{iCL}$ systems were highly clustered and most common in regions with dense cropland (Figure 3a). Municipalities with Embrapa experiments, state inspected slaughterhouses and higher per capita GDP have more iCL farms, while municipalities where Amaggi Group has a strong presence have fewer iCL farms (Figure 3b; Table 6).

\section{FIGURE 3 - SEE ATTACHMENT}

\section{TABLE 6 - SEE END OF DOCUMENT}

Post-hoc Tukey's tests further showed that municipalities with iCL were not significantly different than soy dominant municipalities (Table 7). At the same time, important differences were found between $\mathrm{iCL}$ municipalities and pasture dominant municipalities with respect to per capita GDP, presence of Embrapa experiments and historical soy area - which are all significantly higher in $\mathrm{iCL}$ municipalities. These same differences are observed between municipalities with $\mathrm{iCL}$ versus municipalities with soy and pasture but no integration, indicating that the presence of both land uses is an insufficient condition for the presence of $\mathrm{iCL}$.

\section{TABLE 7 - SEE END OF DOCUMENT}

\section{Discussion}

\subsection{Information access}

Our results highlight the importance of access to information and knowledge for $\mathrm{iCL}$ occurrence, including education levels, access to technical assistance and proximity to Embrapa $\mathrm{iCL}$ experiments. The higher level of education among $\mathrm{iCL}$ adopters versus specialized ranchers supports previous work indicating that better educated households are more open to innovations (Feder \& Umali 1993; Sunding \& Zilberman 2001). This finding is noteworthy in our 
case given how little variation exists in education amongst rural producers in Mato Grosso (IBGE 2006). It also underscores the importance of farm succession for the adoption of agricultural innovations (Ingram et al. 2013), as the transition from specialized to integrated systems is frequently initiated by younger generations who go to urban areas to get formal training in agronomy or animal sciences. Without these younger generations, farmers may be unaware of specific farming practices or unmotivated to change their current practices to increase productivity (Inwood \& Sharp 2012). Higher levels of $\mathrm{iCL}$ in municipalities with Embrapa iCL experiments indicate that these initiatives are critical in providing access to information about iCL through the direct exposure of farmers to these systems. Farmers' geographic and cultural backgrounds are also important; many of the farmers who migrated to Mato Grosso from Southern Brazil have a long history of crop farming, while farmers born in the Center-west have a higher exposure to beef cattle rearing (Jepson 2006). These cultural aspects create differences in informal knowledge among the producers in Mato Grosso and may also explain divergent preferences related to risk and complexity, which directly influence the adoption of complex agricultural systems (Hardaker et al. 2004). Reinforcing feedback loops between culture, land use and risk perceptions often create inertia with respect to innovations (Pannel et al. 2006). Farmers may only overcome this by directly seeing the benefits of these systems in action, e.g. via Embrapa experiments and demonstration plots. The high marginal effect of technical assistance on $\mathrm{iCL}$ occurrence (Table 4) and the high regression coefficient obtained for Embrapa experiments (Table 6) clearly indicate that investments in extension services could yield substantial results in terms of iCL expansion.

\subsection{Supply chain infrastructure}

Higher levels of iCL occurrence around existing soy production regions and slaughterhouses underscores the importance of historical land use trajectories and supply chain infrastructure. This corroborates previous studies showing that a wide range of retailers, credit providers, processers and traders are necessary to provide inputs, equipment and capital for on-farm production. Besides, they also prepare products for long distance transport and export, and provide the logistics and transportation services needed to access distant export markets for these global food commodities (Porter 2000; Brady \& Irwin 2011; Garrett et al. 2013b).

The difference between "SoPa" and "iCL" may suggest that centrality relative to well established agricultural production centers in Mato Grosso is more of a determinant to $\mathrm{iCL}$ 
occurrence then the proximity to soy itself. However, it is important to highlight that the production of soy in SoPa municipalities is a lot smaller than in Soy municipalities (Table S9). Together with (i) the regression results on the significance of the historic soy area, (ii) the relative similarity between "iCL" and "So", as well as (iii) the discrepancy between "iCL" and "Pa", this indicates the importance of crop farming supply chain infrastructure for iCL. Indeed, infrastructure is particularly critical for soybean production since the beans must be dried, weighed and checked for quality within a close proximity to where they are grown (Loewer et al. 1994). The fact that the regression coefficient obtained for soy is greater than that for cattle (Table 6) might be a reflection of that. Regions within Brazil that have a longer history and density of soy production tend to have a much higher diversity and number of related agribusinesses and infrastructure (Garrett et al. 2013a). On the other hand, historical specialization in soy production can also generate land use lock-in.

A somewhat similar effect can be observed with regards to the presence of the Amaggi Group. The occurrence of $\mathrm{iCL}$ is significantly lower around the company's supply chain hubs. Amaggi's unique market niche in higher value, environmentally responsible soy markets (Garrett et al. 2013c) might cause the opportunity costs of $\mathrm{iCL}$ to be too high in regions of particularly profitable specialized soybean production. In these regions, farmers tend to have little incentive to adopt alternative forms of production (e.g. iCL) since they would be forgoing certain high incomes to invest in a new, potentially lower income land use alternative.

\subsection{Capital availability}

The importance of capital availability is demonstrated by our findings that $\mathrm{iCL}$ occurrence is more common among farmers' with lower level of indebtedness and in regions with higher GDP per capita. Although the coefficients obtained for these two variables were relatively small compared to those of other predictors of $\mathrm{iCL}$ occurrence, their effect is not negligible. Large sums of money are often necessary to acquire the machinery, seeds and fertilizer needed to undertake crop production or to purchase animals and establish fencing and watering infrastructure. Such capital outlays would hardly be possible for a rural producer who has already incurred high levels of debt and has a low income. Besides, the apparent irrelevance of credit for $\mathrm{iCL}$ adoption may be partly explained by its poor geographic allocation, bureaucracy and unpreparedness of bank agents responsible for issuing the credit, as identified by other preliminary assessments of the ABC Plan (SENAR 2013; IPAM 2015). However, where credit is 
available, the absence of infrastructure and information poses barriers to $\mathrm{iCL}$, indicating that interventions exclusively based on credit provision are not sufficient to ensure the wide-scale occurrence of complex agricultural innovations.

\subsection{Labor}

The literature offers contrasting evidence concerning labor demands of mixed versus specialized production systems. Integration results in more continuous labor requirements throughout the year, in contrast to the seasonal nature of labor demands for specialized crop production (Thornton \& Herrero 2015). Yet, this occurrence may result in increased labor efficiency if labor is better allocated to productive uses (Hoekstra 1987; Lee 2005). Within Brazil, prior studies have showed that mixed crop and livestock systems do result in higher labor demands and costs, which can profoundly influence management decisions (De Souza Filho et al. 1999; Caviglia \& Kahn 2001). However, our analysis showed no significant association between $\mathrm{iCL}$ occurrence and the number of farm workers at the household level. This is perhaps because many farmers in Mato Grosso do not fully utilize their current labor resources and may be able to take on additional labor tasks without hiring extra permanent or seasonal workers (Gil et al. 2015). Additionally, the labor requirements of $\mathrm{iCL}$ systems in Mato Grosso may be fairly low compared to other forms of integrated crop-livestock production since they are applied at a very large-scale using mechanized planting and harvesting and relatively infrequent pasture rotations.

\subsection{Policy implications}

Our study offers several straightforward insights for land use policy. First, it highlights the need to invest in improved education and technical assistance related to $\mathrm{iCL}$. Besides training and capacity building among technicians, the establishment of social networks and the multiplication of field experiments such as the ones currently conducted by Embrapa could increase exposure to the new technology. Each of these actions should not only address the complexity of $\mathrm{iCL}$ systems, but also be tailored to farmers and ranchers according to specific aspects of $\mathrm{iCL}$ with which each group is less familiar. Investments in education and training are also crucial for a change in paradigm very much needed among producers who traditionally practiced specialized farming. 
Second, the clustering of $\mathrm{iCL}$ occurrence near soy areas reveals that new strategies are sorely needed to promote $\mathrm{iCL}$ in regions dominated by pasture. This is crucial for the achievement of the Brazilian Government's goals to restore degraded lands and increase food production in the country. These strategies include the offer of incentives such as tax exemptions to supply chain actors that establish themselves in key locations, as well as the further promotion of $\mathrm{iCL}$ among ranchers through e.g. targeted credit. Partnerships between ranchers and farmers are another promising alternative to scale up $\mathrm{iCL}$ occurrence while also ensuring the engagement of both groups in the transition from specialized to integrated agriculture. Instead of having a rotation of crops and grasses across different plots within the same farm, rotation could be established among two properties so that both of them are farmed and grazed. This would ensure mutual benefits for farmers and ranchers, particularly knowledge exchange and cost sharing with respect to the acquisition of machinery and animals. The current increase in the number of land rental contracts in Mato Grosso involving the temporary conversion of pastures into cropland (Cohn et al. 2016) could help bring ranchers and farmers together and constitutes a topic worth investigating.

Third, the currently limited relevance of $A B C$ credit for $\mathrm{iCL}$ adoption reveals the need to reassess the underlying strategy of the $A B C$ Credit Program for integration. If targeted at less capitalized ranchers, according to differentiated conditions and in places farther away from existing agricultural hubs (where production costs tend to be higher), credit could possibly make a difference in promoting iCL. As credit provision has been shown to not suffice, it must also be combined with technical support and access to supply chain infrastructure. Furthermore, differentiated credit conditions for $\mathrm{iCL}$ adopters could also help ensure that improvements in supply chain infrastructure and greater access to information would favor $\mathrm{iCL}$ adoption instead of further promoting specialized farming only.

\subsection{Strengths, limitations and future research}

The use of data aggregated at the municipality level allows for the incorporation of a larger geographical surface as well as certain infrastructural variables that cannot be as easily captured at the household level. However, it also entails "simplifying assumptions about the homogeneity of the decision makers and the dynamics comprising that aggregate" (Lesschen et al. 2005, p. 22). The use of household data in our analysis thus complements the municipality level analysis by revealing the importance of individual preferences and knowledge for changing agricultural 
behavior and by highlighting the diversity among rural producers. Although $\mathrm{iCL}$ diffusion depends on specific individual and regional conditions, our analysis suggests that early adoption of iCL might be explained primarily by household characteristics, while its broader occurrence will ultimately depend on regional constraints.

Analyzing the farm and municipality scales simultaneously allows us to examine the interplay between constraints and incentives at different scales. It also highlights interesting areas of convergence and enhances understanding of the generalizability of results between scales. This approach allows for policy recommendations that can be better targeted and/or tailored to individual objectives by revealing which farmers or regions are most likely to adopt $\mathrm{iCL}$ with only a small adjustment in policy as opposed to those that require a more transformative change. Likewise, the prevalence of $\mathrm{iCL}$ occurrence in soy dominant areas reveals the need to increase incentives for integration in other areas of the state as well.

Nevertheless, these results should be interpreted carefully. First, the small number of current $\mathrm{iCL}$ adopters poses an obstacle to the detailed examination of occurrence determinants between different types of iCL. For example, one might expect distance to roads or access to credit to influence the adoption of more complex $\mathrm{iCL}$ systems differently given their unique implementation and maintenance requirements, yields and management operations. Second, our data clearly captures early adopters who do not always follow a pattern representative of broader adoption (Rogers 2003). Monitoring of the $\mathrm{iCL}$ diffusion process over a longer time period would allow us to check whether the factors associated with $\mathrm{iCL}$ occurrence change among later adopters and what influence municipality development has on adoption decisions.

\section{Conclusion}

By investigating the socioeconomic profile of $\mathrm{iCL}$ adopters and several characteristics of places where $\mathrm{iCL}$ systems occur, we have gained insights into individual and regional factors associated with $\mathrm{iCL}$ occurrence and their influence on the diffusion of these systems. While limited to one state in Brazil, our results may lend insights to challenges and opportunities for climate smart sustainable intensification of cattle production systems in other regions particularly where large-scale commercial agriculture predominates. Our study centered on Mato Grosso, the largest agricultural producing state in Brazil, where pasture degradation, land 
abandonment and extensive ranching practices account for most of the GHG emissions and contribute to high levels of deforestation. Though the $\mathrm{iCL}$ diffusion process in the state is recent and dynamic, we found that access to information, education, culture, supply chain infrastructure and historical land use patterns are the most important factors influencing the early stages of $\mathrm{iCL}$ diffusion. Future policies must take into account both individual and regional variations in these factors when designing programs for $\mathrm{iCL}$ adoption. For instance, policies that address individual capital availability and education needs will not be successful if the regional infrastructure required for both soy and cattle is limited, and vice-versa. Unless training in $\mathrm{iCL}$ is targeted at ranchers in marginal lands and supported through broader investment in supply chain infrastructure, adoption of $\mathrm{iCL}$ in regions with degraded pasture will likely remain low. Ensuring $\mathrm{iCL}$ adoption in these regions over the coming years will be crucial for the achievement of Brazil's dual goal of intensifying agriculture sustainably while reducing GHG emissions.

\section{Acknowledgements}

This study was supported by the United States National Science Foundation Grant No. 1415352 and the Gordon and Betty Moore Foundation. We would like to thank Observatório ABC at FGVSP for the data on ABC loans. J.G. was co-supported by the German Academic Exchange Service (DAAD) through the Food Security Center of the University of Hohenheim and by the CarBioCial research project of the German Federal Ministry of Education and Research (BMBF). R.G. also acknowledges support from Italy's Ministry for Environment, Land and Sea since part of this research was conducted while she was a Giorgio Ruffolo Fellow in Sustainability Science at Harvard University. 


\section{References}

Alves, F.V., Laura, V.A. \& Almeida, R.G. 2015, Sistemas agroflorestais - A agropecuária sustentável, Embrapa, Brasília, DF.

Alvim, F. B., Soares-Filho, B., Merry, F. D., Azevedo, H. S. O., Costa, W. L. S., Coe, M. T., Batista, E. L. S., Maciel, T. G., Sheepers, L. C., Oliveira, A. R., Rodrigues, H. O. 2015. “Cenários para a pecuária de corte Amazônica". IGC/UFMG, Belo Horizonte.

Amaggi Group, AMAGGI Agro > Fazenda [Homepage of Amaggi Group], [Online]. Available: http://amaggi.com.br/divisao-agro/pagina-para-destaque/ [2015]

Angelsen, A. \& Kaimowitz, D. 2008, "Will Livestock Intensification Help Save Latin America's Tropical Forests?", Journal of Sustainable Forestry, vol. 27, no. 1-2.

Assunção, J., Gandour, C. \& Rocha, R. 2012, Deforestation Slowdown in the Legal Amazon: Prices or Policies?, Climate Policy Initiative (CPI) / PUC-Rio, Rio de Janeiro.

Balbino, L.C., Barcellos A.O. \& Stone, L.F. 2011, "Reference Document Crop-Livestock-Forestry Integration", EMBRAPA, vol. 1.

Barona, E., Ramankutty, N., Hyman, G. \& Oliver, T.C. 2010, "The role of pasture and soybean in deforestation of the Brazilian Amazon", Environmental Research Letters, vol. 5, no. 2.

Bilger, M., \& Manning, W. G. 2015, "Measuring overfitting in nonlinear models: A new method and an application to health expenditures". Health economics, vol. 24, no.1, pp. 75-85.

Bolliger A. et al. 2006, "Taking Stock of the Brazilian 'Zero-Till Revolution': A Review of Landmark Research and Farmers' Practice". Advances in Agronomy, vol. 91, pp. 47-110.

Bonaudo, T., Bendahan, A. B., Sabatier, R., Ryschawy, J., Bellon, S., Leger, F., et al. 2014, "Agroecological principles for the redesign of integrated crop-livestock systems." European Journal of Agronomy, vol. 57, pp. 43-51.

Bowman, M., Soares-Filho, B., Merry, F., Nepstad, D., Rodrigues, H. \& Almeida, O. 2012, "Persistence of cattle ranching in the Brazilian Amazon: A spatial analysis of the rationale for beef production", Land Use Policy, vol. 29, no. 3, pp. 558-568.

Brady, M., \& Irwin, E. 2011, "Accounting for spatial effects in economic models of land use: Recent developments and challenges ahead". Environmental and Resource Economics, vol. 48, no. 3, pp. 487-509.

Bungenstab (ed) 2012, Sistemas de Integração Lavoura-Pecuária-Floresta - A Produção Sustentável, 2nd edn, EMBRAPA, Brasília. 
Carvalho, J.L.N., Raucci, G.S., Frazão, L.A., Cerri, C.E.P., Bernoux, M. \& Cerri, C.C. 2014, "Croppasture rotation: A strategy to reduce soil greenhouse gas emissions in the Brazilian Cerrado", Agriculture, Ecosystems \& Environment, vol. 183, pp. 167-175.

Caviglia, J.L. \& Kahn, J.R. 2001, "Diffusion of Sustainable Agriculture in the Brazilian Tropical Rain Forest: A Discrete Choice Analysis", Economic Development and Cultural Change, vol. 49, no. 2, pp. 311-333.

CNA 2012, Guia de financiamento para agricultura de baixo carbono [Financing guide for low carbon agricultre]. Confederação da Agricultura e Pecuária do Brasil, Brasília, DF.

Cohn, A.S., Mosnier, A., Havlík, P., Valin, H., Herrero, M., Schmid, E., O’Hare, M. \& Obersteiner, M. 2014, "Cattle ranching intensification in Brazil can reduce global greenhouse gas emissions by sparing land from deforestation", Proceedings of the National Academy of Sciences, vol. 111, no. 20, pp. 7236-7241.

Cohn, A.S., Gil, J.D.B., Toledo, C., Berger, T. 2016, "Biophysical and socioeconomic influences on pasture to crop conversion in Brazil", Land Use Policy, vol. 55, pp. 108-120.

CONAB 2014, Séries Históricas Relativas às Safras 1976/77 a 2013/14 de Área Plantada, Produtividade e Produção. [Homepage of Companhia Nacional de Abastecimento], [Online]. Available: http://www.conab.gov.br/conteudos.php?a=1252\&t= [2014].

Daugstad, Karoline, Katrina Rønningen, and Birgitte Skar. 2006, “Agriculture as an Upholder of Cultural Heritage? Conceptualizations and Value judgements - A Norwegian Perspective in International Context." Journal of Rural Studies, vol. 22 no. 1, pp. 67-81.

Davidson E. A., Araújo, A. C., Artaxo, P., Balch, J. K., Brown, I. F., Bustamante, M. M. C., Coe, M. T., DeFries, R. S., Keller, M., Longo, M., Munger, J. W., Schroeder, W., Soares-Filho, B. S., Souza, C. M., Wofsy, S. C. 2012, "The Amazon basin in transition". Nature, vol. 481, pp. 321328.

De Souza Filho, H.M., Young, T. \& Burton, M.P. 1999, "Factors Influencing the Adoption of Sustainable Agricultural Technologies: Evidence from the State of Espírito Santo, Brazil", Technological Forecasting and Social Change, vol. 60, no. 2, pp. 97-112.

DeFries, R., Herold, M., Verchot, L., Macedo, M.N. \& Shimabukuro, Y. 2013, "Export-oriented deforestation in Mato Grosso: harbinger or exception for other tropical forests?", Philosophical Transactions of the Royal Society B: Biological Sciences, vol. 368, no. 1619.

Embrapa, ILPF > Buscar Sistemas ILPF [Empresa Brasileira de Pesquisa Agropecuária], [Online]. Available:

http://www.cnpgl.embrapa.br/nova/silpf/index.php?class=SilpSearchForm\&method=onSea $\operatorname{rch}[2015]$

Fan, Y. \& Van den Dool, H. 2004. Climate Prediction Center global monthly soil moisture dataset at $0.5^{\circ}$ resolution for 1948 to present. Journal of Geographical Research, vol. 109. 
FAO 2007, Tropical crop-livestock systems in conservation agriculture - The Brazilian experience, Food and Agriculture Organization, Roma.

Feder, G. \& Umali, D.L. 1993, "The adoption of agricultural innovations: A review", Technological Forecasting and Social Change, vol. 43, no. 3-4, pp. 215-239.

FNP. 2013. Agrianual - Anuário da Agricultura Brasileira [Yearbook of the Brazilian Agriculture]. Informa Economics FNP, Sao Paulo.

Galford, G.L., Melillo, J., Mustard, J.F., Cerri, C.E.P. \& Cerri, C.C. 2010, "The amazon frontier of land-use change: croplands and consequences for greenhouse gas emissions", Earth Interact, no. 14, pp. 1-24.

Garrett, R.D., Lambin, E.F. \& Naylor, R.L. 2013a, "The new economic geography of land use change: Supply chain configurations and land use in the Brazilian Amazon", Land Use Policy, vol. 34, pp. 265-275.

Garrett, R.D., Lambin, E.F. \& Naylor, R.L. 2013b, "Land institutions and supply chain configurations as determinants of soybean planted area and yields in Brazil", Land Use Policy, vol. 31, pp. 385-396.

Garrett, R. D., Rueda, X., \& Lambin, E. F. 2013c, "Globalization's unexpected impact on soybean production in South America: Linkages between preferences for non-genetically modified crops, eco-certifications, and land use". Environmental Research Letters, vol. 8, no. 4.

Garrett, R.D., Gil, J.D.B. \& Valentim, J.F. 2015, "Technology transfer: challenges and opportunities for ICLF adoption in the Brazilian Legal Amazon." in Integrated crop-livestockforestry systems: A Brazilian experience for sustainable farming, eds. D.J. Bungenstab, R.G. Almeida, V.A. Laura \& L.C. Balbino, Empraba, Brasília, DF.

Gasparri, N.I., Grau, H.R. \& Gutiérrez Angonese, J. 2013, "Linkages between soybean and neotropical deforestation: Coupling and transient decoupling dynamics in a multi-decadal analysis", Global Environmental Change, vol. 23, no. 6, pp. 1605-1614.

Gibbs, H.K., Rausch, L., Munger, J., Schelly, I., Morton, D.C., Noojipady, P., Soares-Filho, B., Barreto, P., Micol, L. \& Walker, N.F. 2015, "Brazil's Soy Moratorium", Science, vol. 347, no. 6220, pp. 377-378.

Gil, J., Siebold, M. \& Berger, T. 2015, "Adoption and development of integrated crop-livestockforestry systems in Mato Grosso, Brazil", Agriculture, Ecosystems \& Environment, vol. 199, pp. 394-406.

Godar, J., Gardner, T.A., Tizado, E.J. \& Pacheco, P. 2014, "Actor-specific contributions to the deforestation slowdown in the Brazilian Amazon", Proceedings of the National Academy of Sciences, vol. 111, no. 43, pp. 15591-15596. 
Godfray, H.C.J., Beddington, J.R., Crute, I.R., Haddad, L., Lawrence, D., Muir, J.F., Pretty, J., Robinson, S., Thomas, S.M. \& Toulmin, C. 2010, "Food Security: The Challenge of Feeding 9 Billion People", Science, vol. 327, no. 5967, pp. 812-818.

Government of Brazil 2009, Política Nacional de Mudancas Climáticas [Brazilian National Policy for Climate Change]. Available: http://www.planalto.gov.br/ccivil_03/_ato20072010/2009/lei/l12187.htm [2015, May].

Government of Brazil 2011, Plano Setorial de Mitigação e de Adaptação às Mudanças Climáticas para a Consolidação de uma Economia de Baixa Emissão de Carbono na Agricultura - Plano $A B C$ (Agricultura de Baixa Emissão de Carbono) [Sectoral plan for climate change mitigation and adaptation], MAPA [Ministry of Agriculture, Livestock, and Supply], Brasília.

Government of Brazil 2013, Politica nacional de Integracao Lavoura-Pecuaria_floresta [Brazilian National Policy of Integrated Crop-Livestock-Forestry Systems]. Available: http://www.planalto.gov.br/ccivil_03/_Ato2011-2014/2013/Lei/L12805.htm [2015, May].

Government of Brazil 2014, Agriculture and Ranching Plan 2014/15 [Homepage of Bovespa], [Online]. Available: http://www.bmfbovespa.com.br/ptbr/download/Arquivo1.pd [2014, Oct].

Hardaker, J.B., Huirne, R.B.M., Anderson, J.R. \& Lien, G. 2004, Coping with Risk in Agriculture, CABI International, New York.

Hoekstra, D. 1987, "Economics of agroforestry". Agroforestry Systems, vol. 5, pp. 293-300.

Hoelle J. 2011, "Convergence on cattle: Political ecology, social group perceptions, and socioeconomic relationships in Acre, Brazil". Culture, Agriculture, Food and Environment, vol. 33, pp. 95-106.

IBGE, National Agricultural Census 2006 [Homepage of Instituto Brasileiro de Geografia e Estatística], [Online]. Available: www.ibge.gov.br [2014].

IBGE, Downloads - Geociências [Homepage of Instituto Brasileiro de Geografia e Estatística], [Online]. Available: http://downloads.ibge.gov.br/downloads_geociencias.htm [2016].

IMEA 2010, Bovinocultura Mato-Grossense - Caracterização da Bovinocultura no Estado de Mato Grosso, Instituto Mato-Grossense de Economia Agropecuária, Cuiabá, MT.

INCRA, National Rural Registry System (Sistema Nacional de Cadastro Rural). [Homepage of the Brazilian Ministry of Agrarian Development and National Institute for Colonization and Agrarian Reform], [Online]. Available: http://www.incra.gov.br [2012]

Ingram, J., Gaskell, P., Mills, J. 2013, "Incorporating agri-environment schemes into farm development pathways: a temporal analysis of farmer motivations". Land use policy, vol. 31, pp. 267-79. 
INPE 2015, Projeto PRODES - Monitoramento da Floresta Amazonica Brasileira por satélite [Homepage of Instituto National de Pesquisas Espaciais], [Online]. Available: http://www.obt.inpe.br/prodes/index.php [2015, Jan].

Inwood, S.M., Sharp, J.S. 2012, "Farm persistence and adaptation at the rural-urban interface: succession and farm adjustment". Journal of Rural Studies, vol. 28, no. 1, pp. 107-17.

IPAM 2014, The Increase in Deforestation in the Amazon in 2013: a point off the curve or out of control?, IPAM, AMAZON \& ISA.

IPAM. 2015, "Metas do Plano ABC em Mato Grosso devem ser revisadas" [Targets of ABC Plan in Mato Grosso Must Be Revised]. Available at: http://www.ipam.org.br/noticias/Metas-doPlano-ABC-em-Mato-Grosso-devem-ser-revisadas/3287. Accessed September, 2015.

Jepson, W. 2006, "Private agricultural colonization on a Brazilian frontier, 1970-1980", Journal of Historical Geography, vol. 32, no. 4, pp. 839-863.

Klink, C.A., Machado, R.B. 2005, "Conservation of the Brazilian Cerrado". Conservation Biology, vol. 19, pp. 707-713.

Knowler, D. \& Bradshaw, B. 2007, "Farmers' adoption of conservation agriculture: A review and synthesis of recent research", Food Policy, vol. 32, no. 1, pp. 25-48.

Lambin E.F., Meyfroidt, P. 2011, "Global land use change, economic globalization, and the looming land scarcity". Proceedings of the National Academy of Sciences of the United States of America, vol. 108, pp. 3465-3472.

Lee, D.R. 2005, "Agricultural Sustainability and Technology Adoption: Issues and Policies for Developing Countries", American Journal of Agricultural Economics, vol. 87, no. 5, Proceedings Issue, pp. 1325-1334.

Lemaire, G., Franzluebbers, A., Carvalho, P.C.d.F. \& Dedieu, B. 2014, "Integrated crop-livestock systems: Strategies to achieve synergy between agricultural production and environmental quality", Agriculture, Ecosystems \& Environment, vol. 190, pp. 4-8.

Lesschen, J.P., Verburg, P.H. \& Staal, S.J. 2005, Statistical methods for analysing the spatial dimension of changes in land use and farming systems - Land-Use and Land-Cover Change (LUCC), International Geosphere-Biosphere Programme (IGBP), The International Livestock Research Institute \& LUCC Focus 3 Office - Wageningen University, Kenya / The Netherlands.

Loewer OJ, Bridges TC, Bucklin RA. On-farm drying and storage systems. American Society of Agricultural Engineers. CAB Direct; 1994. ISBN 0-929355-53-9.

Macedo, M.N., DeFries, R.S., Morton, D.C., Stickler, C.M., Galford, G.L. \& Shimabukuro, Y.E. 2012, "Decoupling of deforestation and soy production in the southern Amazon during the late 2000s", Proceedings of the National Academy of Sciences. 
Mann, M.L., Kaufmann, R.K., Bauer, D.M., Gopal, S., Nomack, M., Womack, J.Y., Sullivan, K. \& Soares-Filho, B.S. 2014, "Pasture conversion and competitive cattle rents in the Amazon", Ecological Economics, vol. 97, pp. 182-190.

Morton, D. C., Defries, R. S., Shimabukuro, Y. E., Anderson, L. O., Arai, E., del Bon Espirito-Santo, F., et al. 2006, "Cropland expansion changes deforestation dynamics in the southern brazilian amazon". Proceedings of the National Academy of Sciences, vol. 103, no. 39, pp. 14637-14641.

Nepstad, D., Soares-Filho, B.S., Merry, F., Lima, A., Moutinho, P., Carter, J., Bowman, M., Cattaneo, A., Rodrigues, H., Schwartzman, S., McGrath, D.G., Stickler, C.M., Lubowski, R., Piris-Cabezas, P., Rivero, S., Alencar, A., Almeida, O. \& Stella, O. 2009, "The End of Deforestation in the Brazilian Amazon", Science, vol. 326, no. 5958, pp. 1350-1351.

Nepstad, D., McGrath, D., Stickler, C., Alencar, A., Azevedo, A., Swette, B., Bezerra, T., DiGiano, M., Shimada, J., Seroa da Motta, R., Armijo, E., Castello, L., Brando, P., Hansen, M.C., McGrath-Horn, M., Carvalho, O. \& Hess, L. 2014, "Slowing Amazon deforestation through public policy and interventions in beef and soy supply chains", Science, vol. 344, no. 6188, pp. 1118-1123.

New, M., Lister, D., Hulme, M., Makin, I. 2002. A high-Resolution dataset of surface climate over global land areas. Climate Research, vol. 21, pp. 1-25.

Nielsen, Jonas Østergaard, and Anette Reenberg. 2010, "Cultural Barriers to Climate Change Adaptation: A Case Study from Northern Burkina Faso." Global Environmental Change, vol. 20, no. 1, pp. 142-52.

Observatorio ABC 2013, Agricultura de Baixa Emissão de Carbono: Financiado a Transição Análise dos recursos do Programa $A B C$, Fundação Getúlio Vargas.

Observatorio ABC 2014a, Agricultural de Baixa Emissao de Carbono: A Evolucao de um Novo Paradigma, Fundacao Getulio Vargas, Sao Paulo.

Observatorio ABC 2014b, Analise dos recursos do Programa ABC - Visao Regiona, Fundacao Getulio Vargas, Sao Paulo.

Oliveira, P. P. A., Boaretto, A. E., Trivelin, P. C. O., Oliveira, W. S., \& Corsi, M. 2003, "Liming and fertilization to restore degraded brachiaria decumbens pastures grown on an entisol". Scientia Agricola, vol. 60 no. 1.

Overmars K.P., de Koning G.H.J. and Veldkamp A. 2003, "Spatial autocorrelation in multi-scale land use models". Ecological Modelling, vol. 164, pp.257-270.

Pannell, D.J., Marshall, G.R., Barr, N. 2006, "Understanding and promoting adoption of conservation practices by rural landholders". Animal Production Science, vol. 46, no. 11, pp. 1407-24. 
Peres, C.A., Gardner, T.A., Barlow, J., Zuanon, J., Michalski, F., Lees, A.C., Vieira, I.C.G., Moreira, F.M.S. \& Feeley, K.J. 2010, "Biodiversity conservation in human-modified Amazonian forest landscapes". Biological Conservation, vol. 143, no. 10, pp. 2314-2327.

Peron, A.J. \& Evangelista, A.R. 2004, "Degradação de pastagens em regiões de cerrado." Ciência e Agrotecnologia, vol. 28, no. 3, pp. 655-661.

Porter, M.E. 2000, "Location, Competition, and Economic Development: Local Clusters in a Global Economy", Economic Development Quarterly, vol. 14, no. 1, pp. 15-34.

Pretty, J. \& Uphoff, N. 2002, "Social and human capital for sustainable agriculture" in Agroecological innovations: increasing food production with participatory development, ed. N. Uphoff, Earthscan Publications Ltd., London, UK, pp. 47-57.

Richards, P.D., Myers, R.J., Swinton, S.M. \& Walker, R.T. 2012, "Exchange rates, soybean supply response, and deforestation in South America", Global Environmental Change, vol. 22, no. 2, pp. 454-462.

Rogers, E. 2003. Diffusion of innovations (5th ed.). New York: Free Press.

Salton, J.C., Mercante, F.M., Tomazi, M., Zanatta, J.A., Concenço, G., Silva, W.M. \& Retore, M. 2014, "Integrated crop-livestock system in tropical Brazil: Toward a sustainable production system", Agriculture, Ecosystems \& Environment, vol. 190, pp. 70-79.

Schnepf, R.D., Dohlman, E. \& Bolling, C. 2001, "Ch.4 - Soybeans, Agriculture, and Policy in Brazil" in Agriculture in Brazil and Argentina: Developments and Prospects for Major Field Crops, Outlook No. WRS-013 Economic Research Service/USDA.

SENAR. 2013, "Desembolsos do programa Agricultura de Baixo Carbono cresceram 700\% no último ano-safra, mas seu alcance ainda é baixo" [Disbursements of the Low Carbon Agriculture program increased by $700 \%$ in the last crop year, but its reach is still limited]. Available at: http://www.canaldoprodutor.com.br/comunicacao/noticias/desembolsos-doprograma-agricultura-de-baixo-carbono-cresceram-700-no-ultimo-an. Accessed September, 2015.

SICREDI, Cooperativas [Homepage of SICREDI Institutuição financeira cooperativa], [Online]. Available: https://www.sicredi.com.br/html/nossas-cooperativas/ [2015]

Soares-Filho, B., Moutinho, P., Nepstad, D., Anderson, A., Rodrigues, H., Garcia, R., Dietzsch, L., Merry, F., Bowman, M., Hissa, L., Silvestrini, R. \& Maretti, C. 2010, "Role of Brazilian Amazon protected areas in climate change mitigation", Proceedings of the National Academy of Sciences, vol. 107, no. 24, pp. 10821-10826.

Spera, S.A., Galford, G.L., Coe, M.T., Macedo, M.N. \& Mustard, J.F. 2016, "Land-Use Change Affects Water Recycling in Brazil's Last Agricultural Frontier", Global Change Biology. 
Spera, S.A., Cohn, A.S., VanWey, L.K., Mustard, J.F., Rudorff, B.F., Risso, J. \& Adami, M. 2014, "Recent cropping frequency, expansion, and abandonment in Mato Grosso, Brazil had selective land characteristics", Environmental Research Letters, vol. 9, no. 6, pp. 064010.

Stickler, C. M., \& Almeida, O. T. 2008, "Harnessing international finance to manage the Amazon agro-industrial explosion? The case of international finance corporation loans to Grupo Maggi", Journal of Sustainable Forestry, vol. 27, pp. 57-86.

Strassburg, B.B.N., Latawiec, A.E., Barioni, L.G., Nobre, C.A., da Silva, V.P., Valentim, J.F., Vianna, M. \& Assad, E.D. 2014, "When enough should be enough: Improving the use of current agricultural lands could meet production demands and spare natural habitats in Brazil", Global Environmental Change, vol. 28, pp. 84-97.

Sulc, R.M. \& Tracy, B.F. 2007, "Integrated crop-livestock systems in the U.S. corn belt", Agronomy Journal, vol. 99, pp. 335-345.

Sunding, D. \& Zilberman, D. 2001, "Chapter 4 The agricultural innovation process: Research and technology adoption in a changing agricultural sector" in Handbook of Agricultural Economics Elsevier, pp. 207-261.

Thornton, P. K., \& Herrero, M. (2015). Adapting to Climate Change in the Mixed Crop and Livestock Farming Systems in Sub-Saharan Africa. Nature Climate Change, 5, 830-836.

Tilman, D., Balzer, C., Hill, J. \& Befort, B.L. 2011, "Global food demand and the sustainable intensification of agriculture", Proceedings of the National Academy of Sciences, vol. 108, no. 50 , pp. $20260-20264$.

VanWey, L.K., Spera, S., de Sa, R., Mahr, D. \& Mustard, J.F. 2013, "Socioeconomic development and agricultural intensification in Mato Grosso", Philosophical Transactions of the Royal Society B: Biological Sciences, vol. 368, no. 1619.

Vera-Diaz, M. C., R. K. Kaufmann, D. C. Nepstad, and P. Schlesinger. 2008, "An Interdisciplinary Model of Soybean Yield in the Amazon Basin: The Climatic, Edaphic, and Economic Determinants." Ecological Economics vol. 65, no. 2, pp. 420-31.

Walker, R., Browder, J., Arima, E., Simmons, C., Pereira, R., Caldas, M., Shirota, R. \& Zen, S.d. 2009, "Ranching and the new global range: Amazônia in the 21st century", Geoforum, vol. 40, no. 5, pp. 732-745.

Wollni, M. \& Brümmer, B. 2012, "Productive efficiency of specialty and conventional coffee farmers in Costa Rica: Accounting for technological heterogeneity and self-selection", Food Policy, vol. 37, no. 1, pp. 67-76. 


\section{TABLES IN MANUSCRIPT}

Table 1 - Description of the variables used in the household-level analysis, collected during field research by the first author in 2012/13.

\begin{tabular}{|c|c|c|c|c|c|}
\hline $\begin{array}{l}\text { Household-level } \\
\text { variables }\end{array}$ & Description & Mean & Std. Dev. & Min & Max \\
\hline \multicolumn{6}{|l|}{ Dependent variable } \\
\hline $\begin{array}{l}\text { iCL adoption by } \\
\text { farmer }\end{array}$ & Binary: Whether the farmer has iCL & \multicolumn{4}{|c|}{ no $(63 \%)$, yes $(37 \%)$} \\
\hline \multicolumn{6}{|l|}{ Capital availability } \\
\hline $\begin{array}{l}\text { Farm ownership } \\
\text { status }\end{array}$ & Binary: Whether the farmer owns the land he works on & \multicolumn{4}{|c|}{ no $(19 \%)$, yes $(81 \%)$} \\
\hline $\begin{array}{l}\text { External financing } \\
\text { sources }\end{array}$ & $\begin{array}{l}\text { Binary: Whether the household relies on any external financing } \\
\text { source }\end{array}$ & \multicolumn{4}{|c|}{ no $(34 \%)$, yes $(66 \%)$} \\
\hline $\begin{array}{l}\text { Level of } \\
\text { indebtedness }\end{array}$ & Continuous: Score - 1 (min.) to 5 (max.) & \multicolumn{4}{|c|}{$0(27 \%), 1(18 \%), 2$ (28\%), $3(20 \%), 4$ (5\%) } \\
\hline \multicolumn{6}{|c|}{ Costs (adoption/non-adoption) } \\
\hline Total farm size & Continuous (in hectares) & 4039 & 2287 & 300 & 27800 \\
\hline $\begin{array}{l}\text { Distance to the } \\
\text { nearest road }\end{array}$ & Continuous (in kilometers) & 10.6 & 17.5 & 0 & 75 \\
\hline \multicolumn{6}{|c|}{ Biophysical suitability } \\
\hline Farm topography & $\begin{array}{l}\text { Continuous: Ranked by interviewee along a scale of } 1 \text { to } 4 \text { with } 1 \\
\text { indicating very flat slopes and } 4 \text { indicating very steep slopes }\end{array}$ & 0.32 & 0.47 & 1 & 4 \\
\hline $\begin{array}{l}\text { Presence of sandy } \\
\text { soils }\end{array}$ & $\begin{array}{l}\text { Binary: Yes or no answer by interviewee as to whether soils with } \\
\text { high amounts of sand (relative to clay and silt) are the } \\
\text { predominant soil texture on the farm }\end{array}$ & \multicolumn{4}{|c|}{ no $(74 \%)$, yes $(26 \%)$} \\
\hline \multicolumn{6}{|l|}{ Labor availability } \\
\hline $\begin{array}{l}\text { Number of farm } \\
\text { workers }\end{array}$ & Continuous (in number of employees) & 3.3 & 1.2 & 3 & 80 \\
\hline \multicolumn{6}{|c|}{ Information \& know-how } \\
\hline Education level & $\begin{array}{l}\text { Categorical: Basic (a), High School (b), Graduate (c), Post- } \\
\text { graduate }(\mathrm{d})\end{array}$ & \multicolumn{4}{|c|}{$a(9 \%), b(41 \%), c(42 \%), d(7 \%)$} \\
\hline $\begin{array}{l}\text { Access to sector } \\
\text { information }\end{array}$ & $\begin{array}{l}\text { Categorical: Index for access to information on agriculture, } \\
\text { climate and/or market }(1,2,3)\end{array}$ & \multicolumn{4}{|c|}{1 (7\%), 2 (11\%), 3 (82\%) } \\
\hline $\begin{array}{l}\text { Access to technical } \\
\text { assistance }\end{array}$ & $\begin{array}{l}\text { Categorical: Index for participation in trainings, visits of extension } \\
\text { services and/or private consultants }(1,2,3)\end{array}$ & \multicolumn{4}{|c|}{$1(44 \%), 2(52 \%), 3(4 \%)$} \\
\hline $\begin{array}{l}\text { Participation in } \\
\text { networks }\end{array}$ & $\begin{array}{l}\text { Categorical: No membership (a), member of professional } \\
\text { associations or unions (b), both (c) }\end{array}$ & 0.77 & 0.43 & 0 & 1 \\
\hline \multicolumn{6}{|c|}{ Willingness to diversify production } \\
\hline $\begin{array}{l}\text { Region of origin - } \\
\text { South }\end{array}$ & Binary: Whether the household comes from Southern Brazil & \multicolumn{4}{|c|}{ no $(46 \%)$, yes $(54 \%)$} \\
\hline \multicolumn{6}{|l|}{ Multiple factors } \\
\hline Double cropping & Continuous (in hectares of maize) & 861 & 875 & 0 & 1 \\
\hline
\end{tabular}


Table 2 - Description of the variables used in the municipality -level analysis and their respective sources.

\begin{tabular}{|c|c|c|c|c|c|c|}
\hline Variable & Description & Source & Mean & $\begin{array}{l}\text { Std. } \\
\text { Dev. }\end{array}$ & Min & Max \\
\hline \multicolumn{7}{|l|}{ Dependent variable } \\
\hline $\begin{array}{l}\text { Number of } \\
\text { properties with iCL }\end{array}$ & $\begin{array}{l}\text { Continuous variable indicating the number of } \\
\text { properties with } \mathrm{iCL} \text { in each of the } 132 \\
\text { municipalities of Mato Grosso included in our } \\
\text { analysis. }\end{array}$ & $\begin{array}{l}\text { Primary data } \\
\text { collection }\end{array}$ & 0.97 & 2.31 & 0 & 16 \\
\hline \multicolumn{7}{|l|}{ Capital availability } \\
\hline Per Capita GDP & Per capita GDP (in BRL/year) in 2014 & IBGE 2014 & 19044 & 13181 & 6608 & 80407 \\
\hline $\begin{array}{l}\text { Presence of credit } \\
\text { union offices }\end{array}$ & $\begin{array}{l}\text { Presence of credit unions (SICREDI) in } 2013 \\
\text { (binary) }\end{array}$ & SICREDI 2015 & \multicolumn{4}{|c|}{ no $(25 \%)$, yes $(75 \%)$} \\
\hline $\begin{array}{l}\text { Access to } A B C \\
\text { loans }\end{array}$ & $\begin{array}{l}\text { Total amount of } A B C \text { loans issued in a given } \\
\text { municipality since the beginning of the } A B C \\
\text { credit program in } 2011 / 12 \text { divided by the } \\
\text { number of properties of that municipality (in } \\
\text { BRL/farm) }\end{array}$ & $\begin{array}{l}\text { Observatório } \\
\text { ABC 2014a }\end{array}$ & 236 & 1003 & 0 & 7805 \\
\hline \multicolumn{7}{|c|}{ Costs (adoption/non-adoption) } \\
\hline Average farm size & $\begin{array}{l}\text { Weighted average size farms for } 5 \text { size } \\
\text { categories: }<500 \text { ha, 500-1000ha, } 1000-2500 \mathrm{ha} \text {, } \\
\text { 2500-5000ha, }>5000 \mathrm{ha}\end{array}$ & INCRA 2012 & 639 & 423 & 266 & 2451 \\
\hline Average land price & Average price of cropland in 2013 (in BRL) & FNP 2013 & 10965 & 4655 & 6000 & 20000 \\
\hline $\begin{array}{l}\text { Average soy } \\
\text { productivity }\end{array}$ & Average productivity of soy (kg/ha) in 2013 & IBGE 2014 & 2324 & 1278 & 0 & 4500 \\
\hline \multicolumn{7}{|c|}{ Supply chain infrastructure } \\
\hline $\begin{array}{l}\text { Presence of } \\
\text { Amaggi Group }\end{array}$ & $\begin{array}{l}\text { Presence of farms owned by the Amaggi Group } \\
\text { in } 2013 \text { (binary) }\end{array}$ & $\begin{array}{c}\text { Amaggi } \\
\text { Group } 2015\end{array}$ & \multicolumn{4}{|c|}{ no $(97 \%)$, yes (3\%) } \\
\hline $\begin{array}{l}\text { Presence of soy } \\
\text { processing unit }\end{array}$ & $\begin{array}{l}\text { Binary variable for whether or not a soy } \\
\text { processing facility exists in the municipality }\end{array}$ & IBGE 2014 & \multicolumn{4}{|c|}{ no $(87 \%)$, yes $(13 \%)$} \\
\hline $\begin{array}{l}\text { Number of } \\
\text { slaughterhouses }\end{array}$ & Number of slaughterhouses in 2012 & $\begin{array}{c}\text { Government } \\
\text { of Brazil } \\
2011 \\
\end{array}$ & 0.3 & 0.6 & 0 & 4 \\
\hline Herd size in 2006 & Number of cattle heads in 2006 & IBGE 2014 & 184657 & 174653 & 0 & 932083 \\
\hline Soy area in 2006 & $\begin{array}{l}\text { Area dedicated to soy farming in } 2006 \text { (in } \\
\text { hectares) }\end{array}$ & IBGE 2014 & 41297 & 85601 & 0 & 597858 \\
\hline \multicolumn{7}{|c|}{ Biophysical suitability } \\
\hline Precipitation & Average monthly rainfall - March-May & $\begin{array}{l}\text { Fan \& Van } \\
\text { Dool } 2004\end{array}$ & 14 & 5 & 973 & 1674 \\
\hline Temperature & Average daily temperature - March -May & $\begin{array}{l}\text { New et al. } \\
2002\end{array}$ & 24 & 1 & 23 & 28 \\
\hline \multicolumn{7}{|c|}{ Information \& know-how } \\
\hline $\begin{array}{l}\text { Presence of } \\
\text { Embrapa } \\
\text { experiments }\end{array}$ & $\begin{array}{l}\text { Presence of farms where Embrapa conducts IS } \\
\text { experiments in } 2014 \text { (binary) }\end{array}$ & $\begin{array}{c}\text { Embrapa } \\
2015\end{array}$ & 0.07 & 0.28 & 0 & 2 \\
\hline $\begin{array}{l}\text { Technical } \\
\text { assistance }\end{array}$ & $\begin{array}{l}\text { Percentage of farmers who received technical } \\
\text { assistance from the government, NGOs, } \\
\text { cooperatives and/or associations }\end{array}$ & IBGE 2014 & 197 & 144 & 15 & 675 \\
\hline
\end{tabular}


Table 1 - Code, description, number of observations, corresponding percentage and cumulative percentage of three new municipality groups.

\begin{tabular}{|c|l|c|c|c|}
\hline $\begin{array}{c}\text { Group } \\
\text { code }\end{array}$ & \multicolumn{1}{|c|}{ Group description } & Frequency & Percentage (\%) & $\begin{array}{c}\text { Cumulative } \\
\text { percentage (\%) }\end{array}$ \\
\hline "iCL" & All municipalities with iCL & 41 & 31.06 \\
\hline “Pa" & Municipalities with pasture and no iCL & 29 & 21.97 & 51.06 \\
\hline "So" & Municipalities with soy only & 13 & 9.85 \\
\hline "SoPa" & $\begin{array}{l}\text { Municipalities with soy and pasture but no } \\
\text { integration }\end{array}$ & 49 & 37.12 & 103 \\
\hline & Total & 132 & 100 & \\
\hline
\end{tabular}

Table 4 - Results of the logistic regression on iCL occurrence at the household level

\begin{tabular}{|c|c|c|c|c|}
\hline \multirow{2}{*}{ Household-level variables } & \multirow{2}{*}{$\begin{array}{c}\text { Odds ratio } \\
\text { coefficients }\end{array}$} & \multirow{2}{*}{ Std. Err. } & \multicolumn{2}{|c|}{ Delta-method } \\
\hline & & & $d y / d x$ & Std.Err. \\
\hline Farm ownership status & 14.94 & 22.56 & 0.131 & 0.065 \\
\hline External financing sources & 1.56 & 1.53 & 0.022 & 0.049 \\
\hline Level of indebtedness & $0.22 * *$ & 0.13 & $-0.073 *$ & 0.025 \\
\hline Total farm size & 1.00 & 0.00 & 0.000 & 0.000 \\
\hline Double cropping & 3.85 & 4.15 & 0.065 & 0.050 \\
\hline Distance to the nearest road & 0.97 & 0.02 & -0.002 & 0.001 \\
\hline Farm topography - flat & 6.30 & 11.71 & 0.089 & 0.088 \\
\hline Presence of sandy soils & 5.37 & 6.86 & 0.085 & 0.064 \\
\hline Number of farm workers & 1.10 & 0.07 & 0.005 & 0.003 \\
\hline Education level & $5.22 * *$ & 3.31 & $0.080 * *$ & 0.026 \\
\hline Access to sector information & $4.43^{*}$ & 3.03 & $0.072^{*}$ & 0.030 \\
\hline Access to technical assistance & $34.04 * *$ & 33.43 & $0.170 * *$ & 0.035 \\
\hline Participation in networks & 10.26 & 13.83 & 0.112 & 0.062 \\
\hline $\begin{array}{l}\text { Region of origin - South } \\
\text { pseudo } \mathrm{R}^{2}=0.754 \text {; adj. } \mathrm{R}^{2}: 0.576\end{array}$ & $0.01^{* *}$ & 0.01 & $-0.250 * *$ & 0.077 \\
\hline
\end{tabular}

Significance level: ${ }^{* *} P<0.01,{ }^{*} P<0.05$. Degrees of freedom: 14 . Number of observations: 145. 
Table 2 - One-way analysis of variance of the five variables identified as significant in the household model. Household groups "iCL", "Famers" and "Ranchers" refer, respectively, to iCL adopters, specialized farmers and specialized ranchers. $* * \mathrm{P}<0.01, * \mathrm{P}<0.05$

\begin{tabular}{|l|llll|cc|}
\hline Household variable & \multicolumn{3}{|c|}{ Groups } & Contrast & Std.Err. \\
\hline \multirow{2}{*}{ Region of origin } & Farmers & vs & iCL & 0.38 & 0.14 \\
& Ranchers & vs & iCL & $1.37^{* *}$ & 0.16 \\
& Ranchers & vs & Farmers & $0.99^{* *}$ & 0.16 \\
\hline \multirow{3}{*}{ Education level } & Farmers & vs & iCL & $-0.69^{* *}$ & 0.13 \\
& Ranchers & vs & iCL & $-0.67^{* *}$ & 0.15 \\
& Ranchers & vs & Farmers & 0.01 & 0.15 \\
\hline \multirow{4}{*}{ Access to technical assistance } & Farmers & vs & iCL & $-0.67^{* *}$ & 0.09 \\
& Ranchers & vs & iCL & $-0.76^{* *}$ & 0.10 \\
& Ranchers & vs & Farmers & -0.09 & 0.10 \\
\hline \multirow{2}{*}{ Access to sector information } & Farmers & vs & iCL & -0.12 & 0.12 \\
& Ranchers & vs & iCL & $-0.37^{*}$ & 0.14 \\
& Ranchers & vs & Farmers & -0.25 & 0.14 \\
\hline \multirow{2}{*}{ Level of indebtedness } & Farmers & vs & iCL & $1.21^{* *}$ & 0.16 \\
& Ranchers & vs & iCL & $-1.05^{* *}$ & 0.19 \\
& Ranchers & vs & Farmers & $-2.26^{* *}$ & 0.19 \\
\hline
\end{tabular}

Table 3 - Results of the OLS regression on the occurrence of iCL at the municipality level

\begin{tabular}{|l|c|c|}
\hline Municipality-level variables & Coef. & Std.Err. \\
\hline Per Capita GDP & $-0.205^{*}$ & 0.104 \\
Presence of credit union offices & 0.002 & 0.166 \\
Access to ABC loans & -0.065 & 0.071 \\
Average farm size & 0.131 & 0.084 \\
Average land price & 0.057 & 0.085 \\
Average soy productivity & 0.019 & 0.078 \\
Presence of Amaggi Group & $-1.012^{*}$ & 0.460 \\
Presence of soy processing unit & 0.079 & 0.208 \\
Number of slaughterhouses & $0.308^{*}$ & 0.123 \\
Herd size in 2006 & -0.024 & 0.080 \\
Soy area in 2006 & $0.657^{* *}$ & 0.095 \\
Precipitation & 0.024 & 0.077 \\
Temperature & 0.012 & 0.078 \\
Presence of Embrapa experiments & $0.901^{* *}$ & 0.296 \\
Technical assistance & -0.007 & 0.073 \\
$\mathrm{R}^{2}=0.419$, adj. $\mathrm{R}^{2}=0.349$ & & \\
\hline Signicance level: $* *$ P<.01** & & \\
\hline
\end{tabular}

Significance level: ** $P<0.01,{ }^{*} P<0.05$. Degrees of freedom: 15. Number of observations: 141. 
Table 4 - Tukey's pairwise comparison of means with equal variance. Municipality groups are: "iCL" (municipalities with iCL), "Pa" (municipalities with pasture), "So" (municipalities with soy) and "SoPa" (municipalities with pasture and soy but no integration).

\begin{tabular}{|c|c|c|c|c|c|}
\hline Municipality -level variables & \multicolumn{3}{|c|}{ Groups } & \multirow{2}{*}{$\begin{array}{c}\text { Contrast } \\
-0.84^{* *}\end{array}$} & \multirow{2}{*}{$\begin{array}{c}\text { Std.Err. } \\
0.23\end{array}$} \\
\hline \multirow{6}{*}{ Per capita GDP } & $\mathrm{Pa}$ & vs & $\mathrm{iCL}$ & & \\
\hline & SoPa & vs & $\mathrm{iCL}$ & $-0.62^{*}$ & 0.20 \\
\hline & So & vs & $\mathrm{iCL}$ & 0.27 & 0.31 \\
\hline & SoPa & vs & $\mathrm{Pa}$ & 0.22 & 0.22 \\
\hline & So & vs & $\mathrm{Pa}$ & $1.11^{* *}$ & 0.32 \\
\hline & So & vs & SoPa & $0.88^{*}$ & 0.30 \\
\hline \multirow{6}{*}{ Number of slaughterhouses } & $\mathrm{Pa}$ & vs & $\mathrm{iCL}$ & -0.22 & 0.15 \\
\hline & SoPa & vs & $\mathrm{iCL}$ & -0.12 & 0.13 \\
\hline & So & vs & $\mathrm{iCL}$ & -0.39 & 0.20 \\
\hline & SoPa & vs & $\mathrm{Pa}$ & 0.09 & 0.15 \\
\hline & So & vs & $\mathrm{Pa}$ & -0.17 & 0.21 \\
\hline & So & vs & SoPa & -0.27 & 0.19 \\
\hline \multirow{6}{*}{ Presence of Amaggi Group } & $\mathrm{Pa}$ & vs & $\mathrm{iCL}$ & -0.05 & 0.04 \\
\hline & SoPa & vs & $\mathrm{iCL}$ & -0.03 & 0.04 \\
\hline & So & vs & iCL & 0.03 & 0.05 \\
\hline & SoPa & vs & $\mathrm{Pa}$ & 0.02 & 0.04 \\
\hline & So & vs & $\mathrm{Pa}$ & 0.08 & 0.06 \\
\hline & So & vs & SoPa & 0.06 & 0.05 \\
\hline \multirow{6}{*}{ Presence of Embrapa experiments } & $\mathrm{Pa}$ & vs & $\mathrm{iCL}$ & $-0.17 *$ & 0.06 \\
\hline & SoPa & vs & $\mathrm{iCL}$ & $-0.15^{*}$ & 0.05 \\
\hline & So & vs & $\mathrm{iCL}$ & -0.09 & 0.08 \\
\hline & SoPa & vs & $\mathrm{Pa}$ & 0.02 & 0.06 \\
\hline & So & vs & $\mathrm{Pa}$ & 0.08 & 0.08 \\
\hline & So & vs & SoPa & 0.06 & 0.08 \\
\hline \multirow{6}{*}{ Soy area in 2006} & $\mathrm{~Pa}$ & vs & $\mathrm{iCL}$ & $-1.11^{* *}$ & 0.22 \\
\hline & SoPa & vs & $\mathrm{iCL}$ & $-0.92 * *$ & 0.19 \\
\hline & So & vs & $\mathrm{iCL}$ & -0.10 & 0.29 \\
\hline & SoPa & vs & $\mathrm{Pa}$ & 0.18 & 0.21 \\
\hline & So & vs & $\mathrm{Pa}$ & $1.01^{* *}$ & 0.31 \\
\hline & So & vs & SoPa & $0.82 *$ & 0.29 \\
\hline
\end{tabular}

Significance level: ${ }^{* *} P<0.01,{ }^{*} P<0.05$. Number of observations: 132. 


\section{CAPTIONS OF FIGURES}

NOTE: Figures were uploaded separately in editable format. In the PDF file available to the reviewers, the order of appearance corresponds to the captions below.

\section{Main text}

Figure 1 - Unique characteristics of $\mathrm{iCL}$ and the occurrence determinants that arise from these characteristics.

Figure 2 - Contrast between iCL adopters, specialized farmers and specialized ranchers with respect to the five variables identified as significant in the household model. Bars indicate means and whiskers indicate variance.

Figure 3 - (a) Map of cropland, pasture and iCL in Mato Grosso's municipalities in 2014/15. (b) Map of iCL, Embrapa experiments, slaughterhouses, soy processing units and the Amaggi Group in Mato Grosso in 2013. Cropland and pasture were acquired from Cohn et al. (2016). Other variables were gathered from public datasets (Table 2). 


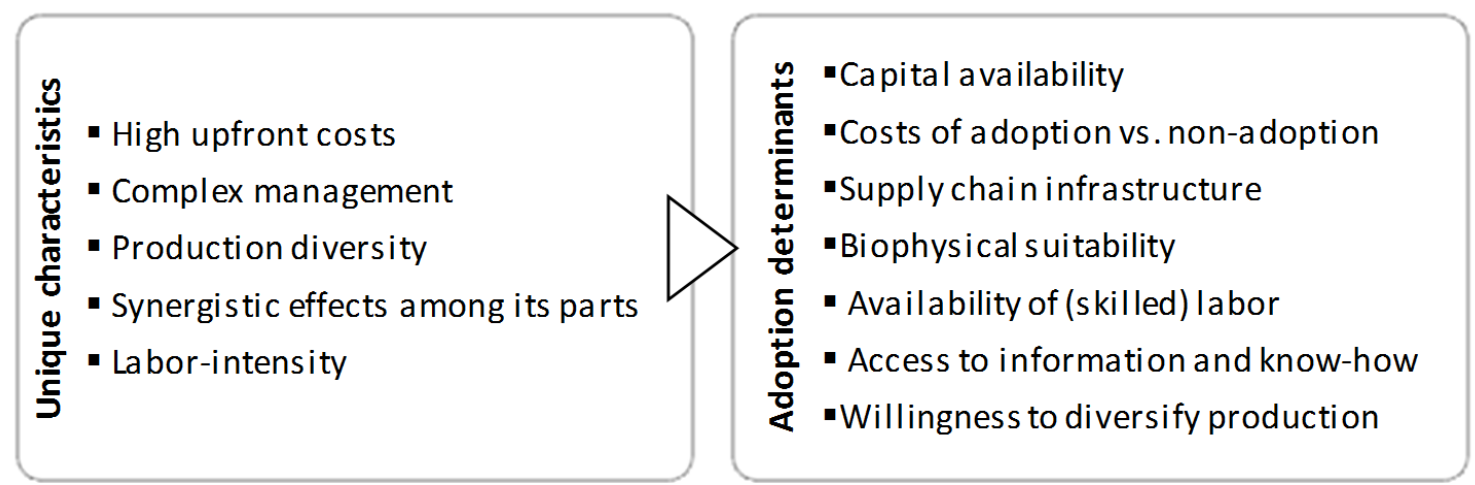



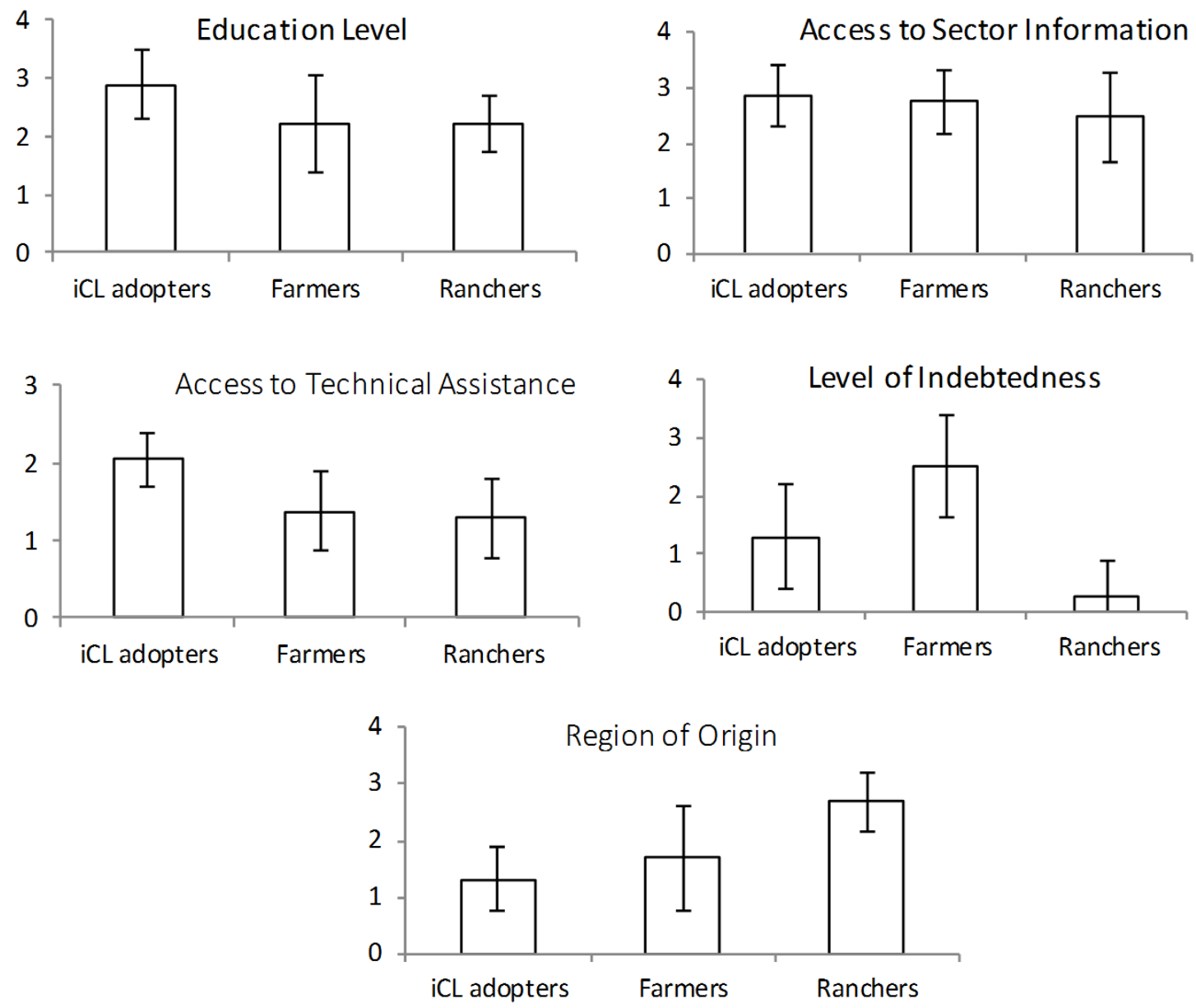

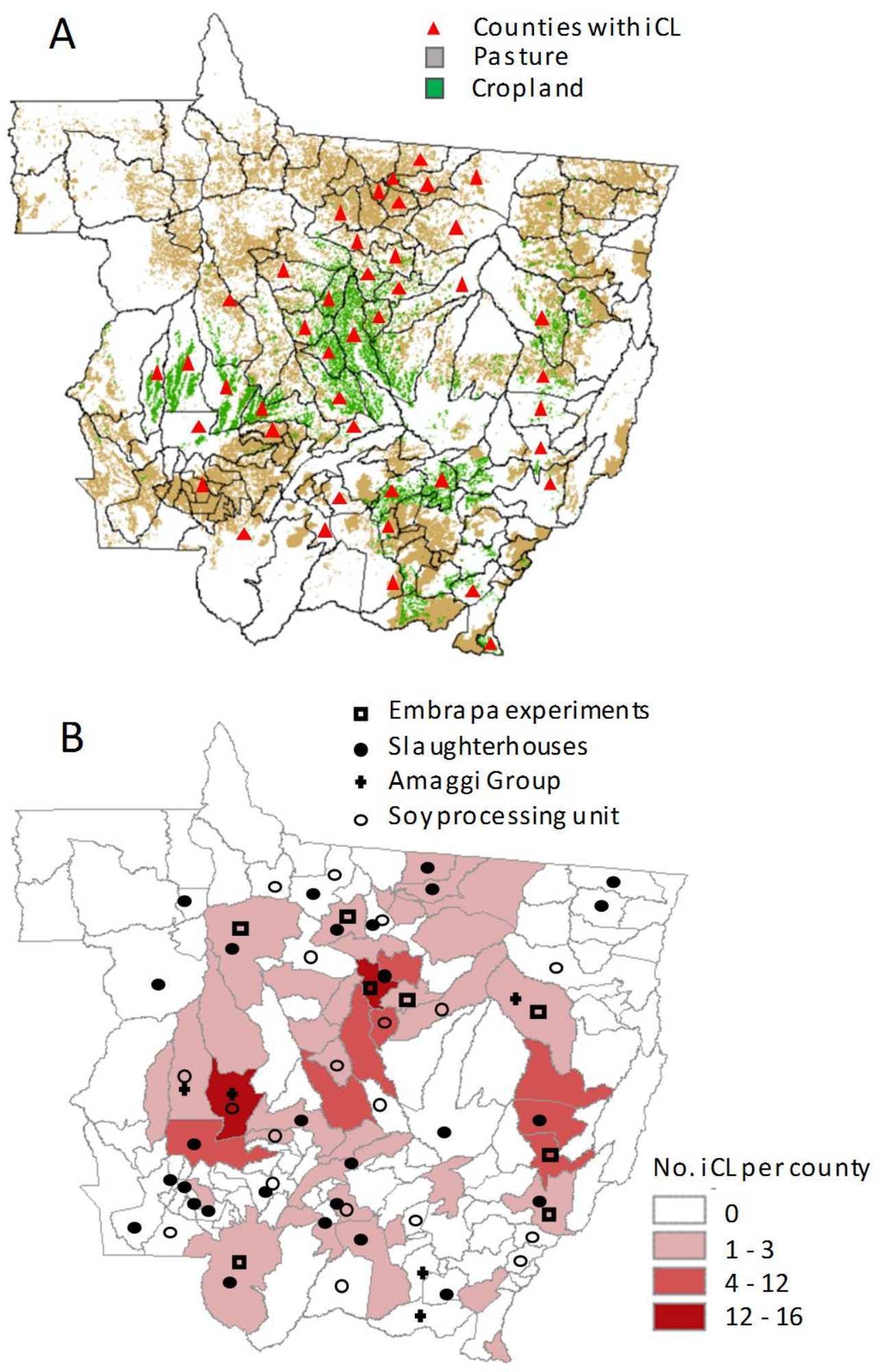